\title{
Analysis of Public Transportation Development Plan for Sustainable Transportation in Padang City
}

\author{
Yuliarti $^{1 *}$, Yulia Hanoselina ${ }^{2}$, and Artha Dini Akmal ${ }^{3}$ \\ ${ }^{123}$ Department of State Administration Science, Faculty of Social Science Universitas Negeri Padang, Padang, \\ Indonesia. \\ *Corresponding author.Email: yuliarti@fis.unp.ac.id
}

\begin{abstract}
The many problems and impacts of transportation form the basis for the policy of developing a mass transit system in Padang City. The purpose of this research is to find out how people's preferences for public transportation are used as a reference for planning the development of public transportation towards sustainable transportation in the city of Padang. This research is quantitative research which is a type of associative quantitative research. The population in this study were residents of the city of Padang who carried out their daily activities in the city of Padang by using the Trans Padang. The collected data were then analyzed using multiple regression techniques. Based on the regression results, it is concluded that partially service quality has a significant effect on people's preferences for Trans Padang with a sig level of $0.00<\alpha=0.05$. Tariffs have a significant effect on people's preferences for Trans Padang with a sig level of $0.05<\alpha=0.05$. Overall the contribution of the dependent variable was $38.7 \%$, with an F-count $>$ F-table (30.261> 3.09). Thus, this study suggests that the government can improve service quality and provide affordable and stable rates for the community. Sustainable transportation development will be realized with a public transportationbased transportation system.
\end{abstract}

Keywords: Planning, Public Transportation, Sustainable Transportation

\section{INTRODUCTION}

Based on the RPJMD of the city of Padang for 2014-2019 the current development plan is to lead to sustainable development. According to the International Union for Conservation of Nature and Natural Resources (IUCN) (1980) in the world conservation strategy defined to achieve sustainable development, the implementation of development in practice must consider social, economic and environmental factors based on living resources, apart from the benefits and losses of the term the short and long-term alternative measures also need consideration.

As a big city with a population of 950,871 people in 2019, it cannot be denied that the level of transportation mobility has become fast and can overcome various transportation problems. Transportation problems that we can encounter today have a negative impact on life, ranging from congestion that can hinder social and even economic activities, air pollution due to vehicle exhaust gases which are certainly dangerous to health and excessive use of fuel oil (Pramyastiwi, Deasy, et al. 2013)
Table 1. Number of Motorized Vehicles by Vehicle Type in Padang City 2017-2019

\begin{tabular}{|l|r|r|r|}
\hline \multirow{4}{*}{$\begin{array}{c}\text { Transportation } \\
\text { Type }\end{array}$} & \multicolumn{4}{|c|}{ Year } \\
\cline { 2 - 4 } & $\mathbf{2 0 1 7}$ & $\mathbf{2 0 1 8}$ & $\mathbf{2 0 1 9}$ \\
\hline A. Passenger Car \\
\hline Sedan & 7.99 & 7.504 & 7.554 \\
\hline Minibus & 74.31 & 70.944 & 81.287 \\
\hline Microbus & 54 & 522 & 675 \\
\hline Bus & 12 & 143 & 164 \\
\hline B. Motorcycle & \multicolumn{4}{|l}{} \\
\hline Two Wheels & 281.20 & 205.5 & 283.08 \\
\hline Tricyle & 35 & 297 & 47 \\
\hline
\end{tabular}

Source: BPS, 2020

In table 1 below, it can be seen that twowheeled motorbikes are the most used type of motorized vehicle with a total of 283,089 units in 2019, this number has increased compared to 2018 which was only 205,529 units. The high growth of two-wheeled motorized vehicles shows the lack of public interest in using public transportation.

In the city of Padang itself, there are several types of public transportation that serve access to the mobility of the people in the city, ranging from nonroute public transportation such as motorcycle taxis, online motorcycle taxis, and taxis, to use these public 
transportation services, people have to pay more. Then public transportation with routes, namely city transportation, and Trans Padang buses, city transportation itself has been operating in the city of Padang for a long time, with a large number of people. comfortable and safe.

In 2014 the Padang city government through the Transportation Agency began operating Bus Rapid Transit (BRT) under the name Trans Padang, in order to support a sustainable transportation system. Sustainable transportation is a transportation system that can harm existing transportation problems such as fuel consumption and high vehicle emissions, security problems, and congestion, and the level of disasters that come for the community so that no losses can be overcome to create (Jenks \& Burgess, 2003).

Sustainable transportation development is one of the solutions offered in overcoming the problem of sustainable development (Sjafruddin, 2012). Based on this, the authors are based on research that conducts research by analyzing public transportation development plans for sustainable transportation in the city of Padang. The analysis was carried out by looking at the extent to which the public's preference for public transportation, in this case, is Trans Padang as transportation that fulfills the concept of sustainable transportation.

\section{METHOD}

This research is quantitative research, quantitative associative type. The population of this research is the inhabitants of the city of Padang who carry out their daily activities in the city of Padang by using the Trans Padang. The data were collected through a Likert-scale questionnaire, data which was also supported by documentation study. The collected data were then analyzed using multiple regression techniques.

\section{RESULT AND DISCUSSION}

Based on the data collected using a questionnaire, it is obtained data that

\subsection{Validity and Reliability Test Results (questionnaire trials)}

\subsubsection{Validity}

Validity is a measure that shows that the measured variable is really a variable that can be researched by researchers (Cooper and Schindler, in Zulganef, 2006).

From the results of the validity test for each variable, both the dependent variable and the independent variable, there are several question items/statements from each variable that are invalid, so the next step is to discard the invalid question or statement items and not enter the item into the questionnaire. which will be distributed to the actual respondents. In this validity test, the researcher did not redistribute the questionnaire, because the researcher felt that there were still valid question/statement items in measuring a variable or indicator in this study.

\subsubsection{Reability}

The benchmark of the reliability test is if the Cronbach Alpha value is more or equal to $\geq 0.6$, the instrument is said to be reliable (Priyatno, 2010).

Table 2. Reability Test

\begin{tabular}{|l|r|}
\hline Variable & Cronbach's Alpha \\
\hline People's preferences & 0.806 \\
\hline Quality service & 0.932 \\
\hline Rates & 0.684 \\
\hline
\end{tabular}

Source : Processed Data, 2020

Based on the table above, the reliability test results obtained with the Cronbach's Alpha value of the three research variables are greater than the value of 0.6 , which means that the instrument can be said to be reliable and can be used for further research.

\subsection{Classic Assumption Test \\ 3.2.1 Multicollinearity Test}

The multicollinearity test is used to determine that the independent variables cannot be significantly related, this test is called the independence test among independent variables.

The test is carried out with the VIF formula, provided that if the VIF value of the independent variable is less than 10.00 , multicollinearity does not occur. The following analysis results are presented in the following table:

Table 3. Multicollinearity Test

\begin{tabular}{|l|l|l|c|}
\hline \multirow{2}{*}{ Model } & \multicolumn{2}{|l|}{ Collinearity } & \multirow{2}{*}{ Information } \\
\cline { 2 - 3 } & Toleranc & VI & \\
\hline X1 & 0.548 & 1.826 & $\begin{array}{c}\text { Not occur } \\
\text { multicoliearit } \\
\text { Quality_servic }\end{array}$ \\
X2 (Rates) & 0.548 & 1.826 & as \\
\hline
\end{tabular}

Source : Processed Data, 2020

\subsubsection{Heteroscedasticity Test}

In this study, the hetecodasticity test was carried out using the Glejser test. This test is done to see whether the variance of each variable is homogeneous or there is no heteroscedasticity. From the data analysis obtained the results of the heteroscedasticity test as shown in the following table 
Table 4. Heteroscedasticity Test

\begin{tabular}{|l|r|l|}
\hline \multicolumn{1}{|c|}{ Model } & Sig & Information \\
\hline X1 & 0,653 & $\begin{array}{c}\text { Not occur } \\
\text { heterocedasticity }\end{array}$ \\
\hline X2 (Rates) & 0,630 & \\
\hline
\end{tabular}

Source : Processed Data, 2020

\subsubsection{Normality test}

To find out whether the distribution of a data follows a normal distribution. Good data is data that has a pattern like a normal distribution (Idris, 2004).
Based on the table below, it can be seen that the results of the analysis carried out with the One-Sample Kolmogorov-Smirnov Test obtained the Asymp. Sig significance results. (2- tailed) is greater than $\alpha=0.05$, namely 0.443 , it can be concluded that the data in this study are normally distributed.

\subsection{Multiple Regression Analysis}

This analysis aims to determine the effect of each independent variable $(\mathrm{X})$ on the dependent variable $(\mathrm{Y})$. The results of multiple linear regression data analysis can be seen in the table below.

Table 5. Multiple Regression Analysis

\begin{tabular}{|l|c|c|c|c|c|}
\hline \multicolumn{1}{|c|}{ Independent Variables } & $\begin{array}{c}\text { Regression } \\
\text { Coeffient }\end{array}$ & $\begin{array}{c}\text { Std } \\
\text { Error }\end{array}$ & t-hit & Sig & Information \\
\hline (constant) & 8.020 & 2.229 & 3.488 & .000 & \\
\hline X1 (Quality_service) & .312 & .045 & 6.921 & .000 & Significant \\
\hline X2 (Rates) & -.590 & .302 & -1.952 & .054 & Significant \\
\hline Dependent Variable : Y (People's_preference) \\
\hline $\begin{array}{l}\text { R Square : 0,387 } \\
\text { Multiple R : 0,662 }\end{array}$ \\
\hline F-statistic : 30,621
\end{tabular}

Source : Processed Data, 2020

The above shows a constant value of 8,020, meaning that if the service quality (X1) and the tariff (X2) are fixed, then the people's preference for Trans Padang buses is $80,20 \%$.

The results of the data processing above show that there is a significant influence between service quality (X1) on people's preferences for public transportation (Y) with a sig level of $0.00<\alpha=0.05$ and a form of positive influence. This means that if the quality of service increases by $1 \%$, the community preference for the Trans Padang tends to increase by $31.2 \%$ assuming there are other variables. Service quality is an effort to meet the needs and desires of consumers and the accuracy of its delivery in balancing consumer expectations (Tjiptono, 2007). This is supported by Puspasari's research (2013) which states that service quality needs to be improved for customer satisfaction, consumer satisfaction is their hope in using a product or service.

Then there is a significant influence between tariffs (X2) on people's preferences for public transportation (trans Padang) (Y) with a sig level of 0.05 $<\alpha=0.05$ and a form of negative effect. If the transPadang tariff increases by $1 \%$, the people's preference for the trans-Padang tends to decrease by $59 \%$ with other fixed variables. The magnitude of the influence of the two independent variables on people's preferences for trans Padang is $66.2 \%$. This is supported by research conducted by Raharjo (2018), which states that one of the determining factors for people's preference in using this mode of transportation is tariff.

The value of f-statistical or f-count $(30.261)>f$ table (3.09), shows that simultaneously there is a significant influence between service quality (X1) and tarif (X2) on people's preferences public transportation (trans Padang).

\section{CONCLUSIONS}

Based on the results of data analysis, it can be concluded that the quality of service needs to be improved because it affects people's preferences for public transportation. As for tariffs, the government needs to ensure that prices can be achieved by the community and maintain its stability. Services that are continuously improved and at affordable prices are expected to reduce the use of private vehicles in the community in the future, thus supporting the idea of developing sustainable transportation.

\section{REFERENCES}

[1] Cooper, D.R., dan Schindler, P.S., 2006. business Research Methods. Eight Edition. McGrawHill/Irwin, New York, NY 10020 
[2] Idris, 2004. Quantitative Data Model Analysis with SPSS Program. Padang : MM

[3] [IUCN] International Union for Conservation of Nature and Natural Resources 1980. World conservation strategy: Living resource conservation for sustainable development. Gland: IUCN.

[4] Jenks, M., \& Burgess, R. (2003). Compact cities: Sustainable urban forms for developing countries.

[5] Pramyastiwi, Deasy, dkk. (2013). The quality of railway services as public transportation in order to achieve sustainable transportation (study at PT Kereta Api Indonesia Operation Area 8 Surabaya). Journal of Public Administration, 61-69.

[6] Priyatno, D. 2010. Understanding Statistical Data Analysis with SPSS. MediaKom, Yogyakarta
[7] Puspasari, M., \& Santoso, S. 2013. Analysis of influence of service quality, facilities and prices on customer satisfaction. Diponegoro Journal of Management, Vol.2, No.2, p1-9

[8] Raharjo, R., Amaliah,I \& Haviz, M. 2018. Identification of the Determinants of the Preference of Cimahi City Communities to the Mode of Railway Transportation (Case Study of the Greater Bandung Local Economy Train. Proceedings of Economics

[9] Sjafruddin, A. 2. (2012). Sustainable Regional Transport Development for Increase Economic Competitiveness. Bandung: ITB's Council of Professors.

[10] Tjiptono, F. 2007. Marketing Strategy. Second edition, Yogyakarta: ANDI 